\title{
CAN WE EXPLOIT SUPERNUMERARY SPIKELET AND SPIKE BRANCHING TRAITS TO BOOST BREAD WHEAT (Triticum aestivum L.) YIELD?
}

\author{
RizWAN, M. ${ }^{1}$ - MAHBOOB, W. $.^{1,2}-$ FAHEEM, M. ${ }^{1}-$ ShIMELIS, H. ${ }^{3 *}-$ HAMEED, A. ${ }^{4}-$ SiAL, M. A. ${ }^{1}$ \\ - SHOKAT, S. ${ }^{4,5}$ \\ ${ }^{I}$ Nuclear Institute of Agriculture, Tandojam (Sindh), Pakistan \\ ${ }^{2}$ College of Plant Science and Technology, Huazhong Agricultural University, Wuhan, China \\ ${ }^{3}$ School of Agricultural, Earth and Environmental Sciences, African Centre for Crop \\ Improvement, University of KwaZulu-Natal, Pietermaritzburg, South Africa \\ ${ }^{4}$ Nuclear Institute for Agriculture and Biology, 38000, Faisalabad, Pakistan \\ ${ }^{5}$ Crop Science, Department of Plant and Environmental Sciences, University of Copenhagen, \\ Højbakkegård Allé 13, DK-2630 Taastrup, Denmark \\ ${ }^{*}$ Corresponding author \\ e-mail: shimelish@ukzn.ac.za
}

(Received 28 $8^{\text {th }}$ Jan 2020; accepted $22^{\text {nd }}$ May 2020)

\begin{abstract}
Maintaining population growth and competitiveness of arable lands is forcing plant scientist to develop novel ways to enhance grain yield per plant. Several studies on wheat have demonstrated the manipulation of the number (supernumerary spikelet) and arrangement (spike branching) of spikelets. Several genes ( $F Z P, n d s u$, $\left.m r s 1, q T S 2 A-1, b h, P p d-1, b h^{t}, b h^{m}, s b 1, s b 2, T F L\right)$ controlling supernumerary spikelet and spike branching trait have been reported. Different supernumerary spikelet and branched head wheat germplasm sources (Fen 33, SG203, R107, 166 Schakheli, AUS15910, Kalyan Sona, SWP-BSW1, BS-33, Yupi branching, WCB617 etc.) are also available in the world. However, little is known about the genetic underpinnings, mechanism, plant signaling and physiological aspects of these traits in wheat. Further, these traits are negatively correlated with grain weight and number of tillers per plant and are highly influenced by environmental factors, even tetraploid and hexaploid wheats with reported tendencies of ear branching show different expressions in different environments. In this review, which is a first review report to our knowledge, we have reported the possibilities to exploit these traits to double the number of grains per spike through the use of available supernumerary and branched head germplasm resources and how plant scientists can overcome the negative correlations to develop a sustainable phenotype.
\end{abstract}

Keywords: branched head, environmental factors, food security, germplasm sources, grain yield, spike architecture

\section{Introduction}

World food security is challenged by climate changes and loss of arable land due to urbanization and ever increasing population (Godfray et al., 2010). Therefore, an increase in cereal grain production is required to feed the growing population which is anticipated to rise up to 9 billion by 2050. Bread wheat (Trticum aestivum L.) is one of the most needed food crop in the world. Its yield in terms of grain production/plant mainly depends on the structural design of the inflorescence. Wheat scientists consider that managing spike architecture is one possible way to increase per plant yield. Dobrovolskaya et al. (2015) reported that genetic determinism of inflorescence development may permit new spike architecture to be designed, with the aim of improving grain production. New spike morphology may lead towards increase in the number of spikelets in the spike i.e. making selections for wheat forms with 
supernumerary spikelet and branched spike. These traits are natural variation in wheat inflorescence and holds great potential for boosting bread wheat yield by doubling the number of grains per spike (Li and Zhao, 2000). However, spike branching is negatively correlated with kernel weight and number of tillers per plant. Wheat breeders observed that low kernel weight/size is very problematic and hard to overcome in the branched or supernumeric spikes (Yen et al., 1993). Furthermore, stability of the lines to express spike branching trait is influenced by environmental dynamics such as vernalization, temperature, time of sowing, nutrients availability and photoperiod (Swaminathan et al., 1966; Pennell and Halloran, 1984a). Fortunately, some wheat germplasm is available that show stable expression of branching trait which can be exploited to create desired variation in the architecture of wheat inflorescence and to boost the grain yield. Studies have shown that it is practical to utilize genes underlying spike branching character to develop stable cultivars with more kernel weight and tillering capacity (Poursarebani et al., 2015). The objectives of this review are to: (1) highlight the importance of supernumerary spikelet and spike branching trait and their potential utilization in improving wheat crop productivity, (2) describe the detailed genetic basis including underlying genes, evolution and mechanism of supernumerary spikelets and spike branching trait development in wheat, (3) understand the genetic basis, morpho-physiological, biochemical and molecular aspects, (4) provide knowledge regarding expression of these characters, some stable materials and isogenic lines developed for pyramiding different underlying genes, (5) in the end, environmental factors affecting the expression of supernumerary spikelet and spike branching traits and prospects are highlighted.

\section{Genetics of Supernumerary Spikelet and Spike Branching}

The branching appearance in wheat inflorescence is due to a spontaneous mutation that has been recognized since prehistoric times (Tschermak, 1914; Sharman, 1944). A mutant with adventitious branching in the ears was found in nature in T. turgidum var. mirabile Korn $(2 \mathrm{n}=$ 28). In 1957, a mutant with ear branching was isolated from $\mathrm{M}_{2}$ progeny of T. aestivum var. N. P. $797(2 n=42)$ treated with $10 \mu$ C. per seed of $S^{35}$. Swaminathan $(1966)$ observed that this mutant had about $15 \%$ pollen sterility and $30 \%$ seed sterility and gave rise to both normal and branched ears when seeds were sown from open pollinated heads. The proportion of branched ears was found 9 to $54 \%$ in different years. Later on, spike branching and supernumerary spikelets has been witnessed in diploid (T. monococcum, bh ${ }^{m}$ locus; chromosome 2A ${ }^{\mathrm{m}} \mathrm{S}$; Amagai et al., 2014), tetraploid (T. turgidum, $b h^{t}$ locus; chromosome 2AS; Klindworth et al., 1997; Poursarebani et al., 2015) and hexaploid wheat (T. aestivum, bh genes; chromosome 2AS, 2BS, 2D, 4A, 4B, 5A; Peng et al., 1998; Dobrovolskaya et al., 2015). The loci maintaining the branchless inflorescence are located in syntenic chromosome positions in all the respective genomes. This shows that branch repression in wheat is controlled by major orthologous genes and defects in these genes are responsible for the formation of lateral branching (Poursarebani et al., 2015). These branched heads are distinct in phenotype from the supernumerary spikelets having additional spikelets per node of rachis (Pennell and Halloran, 1983). Fundamental genetic factors for supernumerary spikelet phenotype found to be assorted and exemplified for paired spikelet phenotype (Boden et al., 2015) or multi-rowed spike ( $m r s$ ) locus (Dobrovolskaya et al., 2009). Echeverry-Solarte et al. (2014) reported seven QTLs controlling supernumerary spikelet development located on 2D, 5B, 6A, 6B and 7B chromosome. All the reported genetic factors for supernumerary spikelet and spike branching trait in different wheat germplasm are summarized in Table 1. Despite of 
enduring efforts of scientific community, the phenomenon of laterally formed branches has always remained elusive in wheat.

Table 1. List of the genes responsible for supernumerary spikelet and spike branching in wheat

\begin{tabular}{|c|c|c|c|c|c|}
\hline Gene/locus name & Symbol & $\begin{array}{l}\text { Chromosome } \\
\text { Location }\end{array}$ & Controlled trait & Wheat species & Reference \\
\hline branched head & $b h^{m}$ & $2 \mathrm{~A}^{\mathrm{m}} \mathrm{S}$ & Branched head & T. monococcum & Amagai et al. (2014) \\
\hline branched head & $b h^{t}$ & $2 \mathrm{AS}$ & Branched head & T. turgidum & $\begin{array}{l}\text { Klindworth et al. } \\
\text { (1997), Poursarebani } \\
\text { et al. (2015) }\end{array}$ \\
\hline Frizzy Panicle & $F Z P$ & 2AS,2BS,2DS & $\begin{array}{l}\text { Supernumerary } \\
\text { spikelet }\end{array}$ & T. aestivum & $\begin{array}{c}\text { Dobrovolskaya et al. } \\
\text { (2015) }\end{array}$ \\
\hline QSS-NDSU & $n d s u$ & $2 \mathrm{D}, 5 \mathrm{~B}, 6 \mathrm{~A}, 6 \mathrm{~B}, 7 \mathrm{~B}$ & $\begin{array}{l}\text { Supernumerary } \\
\text { spikelet }\end{array}$ & T. aestivum & $\begin{array}{c}\text { Echeverry- } \\
\text { Solarte et al. (2014) }\end{array}$ \\
\hline monstrosum spike & $m r s 1$ & 2DS & Multi-row spikelet & T. aestivum & $\begin{array}{c}\text { Dobrovolskaya et al. } \\
\text { (2009) }\end{array}$ \\
\hline triple spikelet & $q T S 2 A-1$ & $2 \mathrm{~A}$ & $\begin{array}{l}\text { Supernumerary } \\
\text { spikelet }\end{array}$ & T. aestivum & Li et al. (2011) \\
\hline$B h$ genes & $b h$ & $2 \mathrm{D}, 4 \mathrm{~A}, 4 \mathrm{~B}, 5 \mathrm{~A}$ & Branched head & T. aestivum & Peng et al. (1998) \\
\hline Photoperiod D-1 & Ppd-1 & $2 \mathrm{D}$ & Paired spikelet & T. aestivum & Boden et al. (2015) \\
\hline spike branching & $s b 1, s b 2$ & $2 \mathrm{~A}, 2 \mathrm{D}$ & Spike branching & T. aestivum & Zhang et al. (2012) \\
\hline$L E A F Y$-like gene & $T F L$ & - & Spike branching & T. aestivum & Wang et al. (2017) \\
\hline
\end{tabular}

\section{Evolution \& Domestication}

Modern form of cultivated wheat is one of the oldest cereal crops opted by the early farmers for domestication and improvement (Gross and Olsen, 2010). This domestication represents the course of selection and adaptation of wild relatives based on their versatile genetic background to meet the human needs like taste, yield, cultivation and harvest methods (Gepts, 2004; Lenser and Theiben, 2013). Archeological evidences show that the domestication of wheat started 10000 to 12000 years ago (Doebley et al., 2006) in the Fertile Crescent (Glemin and Bataillon, 2009). The set of traits altered during this process is commonly known as domestication syndrome included alteration in architecture of plant, depletion of toxin compounds, compact growth habit, early maturity and other yield related traits (Konopatskaia et al., 2016). Besides grain yield, shape, and color spike morphological characteristics like spike shape, presence or absence of awns, spike branching and supernumerary spikelets per spike were the key factors which remained the subject of interest for early farmers and breeders.

No literature is reported about the evolution and domestication of branched spike or supernumerary spikelets per spike. The possible reason is the low yield as compared to branchless wheat and that's why early farmers and breeder were reluctant to select branched wheat. However, many scientists reported the presence of branched wheat 
spike as abnormality in spike morphology which appeared rarely in Triticum species (Dobrovolskaya et al., 2017). Pliny the Elder has mentioned the presence of branched spike in T. trugidum 2000 years ago (23-79 AD) under the name of Ramosum and Centigranum (de Candolle, 1883). Some other names like "Miracle wheat", "Mummy", "Egyptian", "Jerusalem wheat", and "Seven-headed" has also been reported in the literature to describe the branching pattern of this tetraploid wheat (Dahlgren, 1922; Dorofeev and Korovina, 1979). This branching pattern in tetraploid wheat is due to the natural mutation which has been known since ancient times (Poursarebani et al., 2015). The character of branched spike is usually exhibited by the tetraploid wheats, that's why all the members of tetraploid wheat having branched spike are classified in a separate group named as T. turgidum convar. compositum (L.f) A. Filat. It is noteworthy that the members of this group possess unique spike morphology which is characterized by the development of additional spikelets on rachis nodes or spikelets appear on the extended rachilla in the form of branching especially in the lower portion of the spike (Dobrovolskaya et al., 2009). This type of branching is known as turgidum type of branching (Dobrovolskaya et al., 2017). The other species of genus Triticum in which branched spikes have been observed are T. dicoccum, T. polonicum, T. spelta and T. vulgare (Masubuchi, 1974; Wang et al., 2016).

\section{Wheat Germplasm Sources with Supernumerary Spikelet and Spike Branching Trait}

Researchers emphasized that current performance of wheat is generally supposed to be sink regulated (Miralles and Slafer, 2007; Lawlor and Paul, 2014). Therefore, spike branching is important for increasing sink capacity and improving the yield potential. Many researchers in the world have developed and maintained germplasm sources/varieties with supernumerary spikelet and spike branching traits. These lines differ in giving stable expression in all kind of favorable and unfavorable environments. However, some stable lines are also present in the world. The detail of such germplasm is presented in Table 2 and pictorial view of supernumerary spikelet and branched head wheat along with normal spike wheat is given in Figure 1.

\section{Role of Phytohormones and Growth Regulators in the Development of Supernumerary Spikelets}

In hetero branching spike the supernumerary spikelet attribute was influenced by light intensity, varied temperature, nutrients balance (Koric, 1975; Peanell and Halloran, 1983) and plant hormones (McSteen and Leyser, 2005). Plant growth and development regulated by natural and synthetic plant growth regulators are being implemented as potential investigation tool to elucidate plant responses on physiological basis or to explore the mechanisms of biochemical control. Among many plant hormones, auxin plays a cardinal role to promote polar growth of floral meristems and all other organ primordia (Cheng and Zhao, 2007; Benjamins and Scheres, 2008; Delker et al., 2008). Localized auxin biosynthesis is resulted from activation of YUC (YUCCA flavinmonooxygenase) genes which indicates that auxin biosynthesis is also necessary for initiation of floral meristem (Zhao, 2008). It is well documented that the role of auxin transport and biosynthesis in axillary meristem initiation is found in monocots (Poursarebani et al., 2015). 
Table 2. Wheats with stable branched head/supernumerary spikelet trait

\begin{tabular}{|c|c|c|}
\hline Line name & History/Country of origin & Reference \\
\hline Gandilyan-2 & From T. durum/Armenian Agriculture Academy, Armenia & Amagai et al. (2017) \\
\hline W-589 Osiris & From T. turgidum/John Innes Centre, Norwich, UK. & Amagai et al. (2017) \\
\hline $\begin{array}{l}\text { TRI 5200, TRI } 900 \\
\text { and TRI } 1777\end{array}$ & $\begin{array}{c}\text { From } T \text {. dicoccon/Leibniz Institute of plant genetics and crop } \\
\text { plant research, Gatersleben, Germany }\end{array}$ & Amagai et al. (2017) \\
\hline k-39297 & $\begin{array}{l}\text { From } T \text {. polonicum/Institute of Cytology and Genetics, } \\
\text { Novosibisrk, Russia. }\end{array}$ & Amagai et al. (2017) \\
\hline $\begin{array}{l}\text { PI } 623936 \\
\text { PI } 349056\end{array}$ & $\begin{array}{c}\text { From } T \text {. durum \& turgidum/National Small Grain Collection, } \\
\text { Aberdeen Idaho, USA }\end{array}$ & Amagai et al. (2017) \\
\hline R107 & From T. durum/Agrotest Fyto Ltd. Czech Republic & Amagai et al. (2017) \\
\hline WCB617 & $\begin{array}{c}\text { Source for the supernumerary spikelet phenotype maintained } \\
\text { by North Dakota State University }\end{array}$ & $\begin{array}{l}\text { Echeverry- } \\
\text { Solarte et al. (2014) }\end{array}$ \\
\hline MC1611 & $\begin{array}{c}\text { Induced mutant of bread wheat with supernumerary spikelet } \\
\text { trait/Altai Research Institute of Agriculture, Russia) }\end{array}$ & $\begin{array}{l}\text { Dobrovolskaya et al. } \\
\text { (2014) }\end{array}$ \\
\hline Fen33 & $\begin{array}{l}\text { Interspecific hybrid of } T \text {. turgidum } \times T \text {. } \\
\text { aestivum/Northwestern wheat zone, China }\end{array}$ & Zhang et al. (2012) \\
\hline $\begin{array}{l}\text { NILs (DD, DR, SR1, } \\
\text { SR2) }\end{array}$ & $\begin{array}{c}\text { BC populations of Fen33 ( } s b \text { gene donor, non-recurrent } \\
\text { parent) and Taishan (recurrent parent)/Shandong Agricultural } \\
\text { University, China }\end{array}$ & Zhang et al. (2012) \\
\hline SG203 & $\begin{array}{l}\text { Elite line selected from a cross between Fen } 33 \text { and Weimai } \\
\text { (common cultivar of wheat zone in Huanghuai, China) }\end{array}$ & Zhao et al. (2012) \\
\hline 166-Schakheli & $\begin{array}{c}\text { Branched spike wheat selected from a cross between } 171 \mathrm{ACS} \\
\text { (a complex wheat line) and Bereketli-95 (durum wheat } \\
\text { variety } T \text {. durum Desf.)/ Genetic Resources Institute, Baku, } \\
\text { Azerbaijan }\end{array}$ & $\begin{array}{l}\text { Aliyeva and Aminov } \\
\qquad(2011)\end{array}$ \\
\hline Yupi branching & $\begin{array}{c}\text { Bread wheat selection which stably expresses supernumerary } \\
\text { spikelet character/Sichuan Agricultural University China }\end{array}$ & Peng et al. (1998) \\
\hline BS33 & $\begin{array}{c}1^{\text {st }} \text { branched spike stable cultivar in the world derived from } T . \\
\text { turgidum } \times T \text {. aestivum } \text { cross/ maintained by Crop Genetics } \\
\text { Institute, Taiyuan }\end{array}$ & Yuan et al. (1994) \\
\hline SWP-BSW1 & $\begin{array}{c}\text { Landrace accession of } T \text {. turgidum with spike branching } \\
\text { trait/Crop development center, University of Saskatchewan, } \\
\text { Canada }\end{array}$ & $\begin{array}{l}\text { Hucl and Fowler } \\
\text { (1992) }\end{array}$ \\
\hline AUS15916 & $\begin{array}{l}\text { Supernumerary spikelet wheat from T. aestivum/CIMMYT, } \\
\text { Mexico }\end{array}$ & $\begin{array}{l}\text { Pennell and Halloran } \\
\text { (1984b) }\end{array}$ \\
\hline $\begin{array}{l}\text { AUS15910 } \\
\text { AUS4531 }\end{array}$ & $\begin{array}{c}\text { Supernumerary spikelet wheat from T. aestivum/Brumley } \\
\text { Plant Sciences Center, Victoria, Australia }\end{array}$ & $\begin{array}{l}\text { Pennell and Halloran } \\
\text { (1983) }\end{array}$ \\
\hline $\begin{array}{l}\text { AUS17335 } \\
\text { AUS17336 }\end{array}$ & $\begin{array}{c}\text { Supernumerary spikelet wheat from T. aestivum/Zagreb, } \\
\text { Yugoslavia }\end{array}$ & Koric (1973) \\
\hline Kalyan Sona & $\begin{array}{c}\text { Indian wheat derived from Mexican stock with ear branching } \\
\text { came from } T \text {. turgidum }\end{array}$ & $\begin{array}{l}\text { Rawson and Ruwali } \\
\qquad(1972 a)\end{array}$ \\
\hline
\end{tabular}




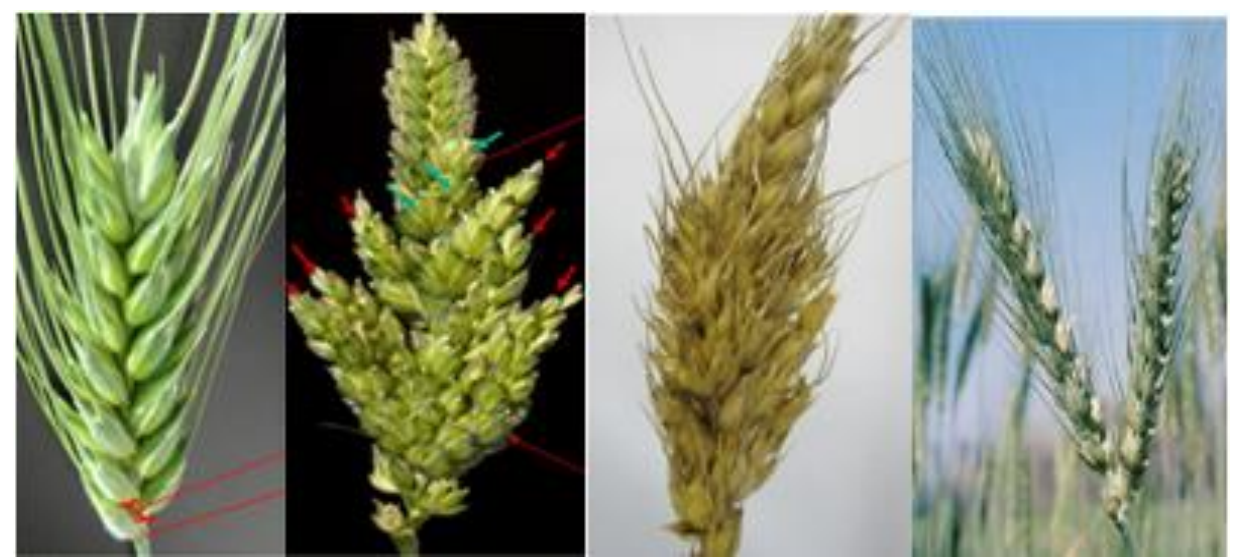

Figure 1. Pictorial view of normal spike along with supernumerary spikelet and branched spike wheat

Plant architecture and reproduction is dependent on axillary meristems that developed in axils of plant leaves. In reproductive growth, flowering branches or flowers produced from axillary meristems, thus during development of grass inflorescence, axillary meristems give rise to branches and spikelets before they give rise to flowers (McSteen et al., 2000; Bommert et al., 2005). Plant hormones and transcription factors controlled the uniqueness and determinacy of various kind of meristem (Bortiri and Hake, 2007; Thompson and Hake, 2009; McSteen, 2009). Hormones play a significantly important role to regulate the branching of shoot and inflorescence (McSteen and Leyser, 2005; Beveridge, 2006; Barazesh and McSteen, 2008; Ongaro and Leyser, 2008). Axillary meristem initiation required auxin for both vegetative and inflorescence development while cytokinin controlled the volume of meristem and consequently affects branching indirectly (Shani et al., 2006; Kyozuka, 2007).

Findings of Tetsuka (2001) provided important information regarding the function of chemical metabolism associated to the genetic aspects and photoperiodism in stimulating the supernumerary spikelet differentiation, by showing overproduction of endogenous concentration of gibberellic acid, nucleic acids and phosphatide in wheat mutant Norin52. Likewise, exogenous application of gibberellic acid and nucleic acids had positively affected the supernumerary spikelets differentiation indicating their role on spikelet developmental phase by influencing chemical metabolism while phosphoric substances and their derivative nucleic-like compound might show their efficacy on differentiation of supernumerary spikelets and rachis branch development. In autumn sowing, exogenously applied uracil and thymine had significantly promoted supernumerary spikelets formation, hence uracil induced the differentiation of the side-type supernumerary spikelets and the thymine stimulated the double-type supernumerary spikelets. Pearce et al. (2013) reported that wheat genotypes expressing VRN1 has positively responded to exogenous application of gibberellins in terms of accelerated spike development. The VRN1 and gibberellic acid's simultaneous existence leads toward up-regulation of floral meristems identity genes ' $L E A F Y$ and SUPPRESSOR OF OVEREXPRESSION OF CONSTANS1-1'.

It is well documented that character of branched rachis was effectively modulated by exogenous auxin which induced interratic branched rachis. Foliage application of Indole-3Acetic Acid (IAA) and Indole-3-Butyric Acid (IBA) $(0.1 \mathrm{mM})$ after two ridge stage of shoot apex, induced maximum increase in quantity of branched rachis by 82.6 and $78.3 \%$ respectively while 2,4-D and Naphthalene acetic acid (NAA) applied at concentration of 1 
$\mathrm{mM}$ produced 57.6 and $46.7 \%$ more branched rachis in comparison with untreated plants. Likewise, whole spike subjected to $1 \mathrm{mM}$ NAA and 2,4-D illustrates improvement in the number of spikelet $57.2 \%$ and $53.4 \%$, correspondingly over non-sprayed plants. Moreover, application of auxins stimulated the expression of $T F L$ gene during the occurrence of branched rachises that designates the central role to auxins in directing the branched spike development and TFL might be correlated with this development of branched rachises in wheat. The newly developed young spike had high level of Indole acetic acid in genotypes having branched spike as compared to normal spike wheat lines. It might be attributed to higher relative expression of TaIAR3, an auxin synthesis related gene, in wheat line having branched spike as compared to normal spike lines (Wang et al., 2017). Therefore, it can be speculated that higher IAA contents might be involved in the development and growth of branched spike in wheat. Floral identity in newly formed floral primordial was stimulated by floral meristem identity genes $L F Y$ and APETALA1 (AP1) in terms of establishment and maintenance of floral identity (Simon et al., 1996). Thus, polar transport of auxin and $L F Y$ coordinately alter flower development by regulating genes needed for growth of the floral organs and might be contributed to branched spike (Yamaguchi et al., 2014). It is also reported that higher level of endogenous IAA positively influenced the expression of FLO/LFY in juvenile vegetative shoot apices and leaf primordia (Wang et al., 2017). It might play a key role in development of inflorescence architecture and regulation of floral meristems initiation in several plant species (Kyozuka et al., 1998; Bomblies et al., 2003).

\section{Molecular Characterization}

Efforts were started in the last century to get the better understanding of genetics of supernumerary or branched spike in tetraploid wheat. The study revealed that trait is regulated by one recessive gene designated as bh, branched head (Percival, 1921; Sharman, 1944). Later on same type of gene action was observed in diploid (T. monococcum) and hexaploid wheat. The gene(s) controlling this trait is resided on the homeologous group 2 which is also affected by other environmental factors (Penell and Halloran, 1983; Klindworth et al., 1990, 1997). Further study in hexaploid wheat elucidated that branching spike is controlled by three different genes names as Normalizator $(\mathrm{Nr})$, Ramifera $(\mathrm{Rm})$ and Tetrastichon $(\mathrm{Ts})$. Among these genes, $R m$ and $T s$ complement each other to produce the branched spike phenotype while the $\mathrm{Nr}$ acts as dominant repressor of branched spike (Koric, 1973). Further studies also supported that spike branching in hexaploid wheat is regulated by three different genes (Penelle and Halloran, 1983; Dencic, 1988). Recently, Dobrovolskaya et al. (2015) showed that the formation of supernumerary spikelets or spike branching in bread wheat is under the control of WHEAT FRIZZY PANNICLE (WFZP) resided on the short arm of homeologous group 2. The molecular characterization of orthologue genes of WFZP in other members of Poaceae family (maize, rice, barley, and sorghum) suggest that this gene belongs to ERF (ethylene-responsive element-binding factor) family of $A P 2$ transcription factors (Chuck et al., 2002) which are meant to function as repressor to the formation of lateral branching of meristem (Komatsu et al., 2003; Zhang et al., 2017). Detailed structural and functional analysis of wheat $W F Z P$ genes revealed the presence of mutations in two homeologous genes i.e. TaWFZR-2A and TaWFZR-2D which are responsible for the formation of branched spike in hexaploid wheat (Dobrovolskaya et al., 2015). Another study in tetraploid wheat $(T$. trugidum) found a mutant allele of WFZP-A designated as TtBH-Al having an amino acid substitution in the DNA binding domain to produce branched spike (Poursarebani et al., 2015). In tetraploid wheat, two types of spike branching phenotypes are found which are 
named as "true spike ramification" and "false-true spike ramification" which have some resemblances in their phenotypes. TtBh-Al is mainly responsible for the true spike ramification phenotype while false-true spike ramification is under the regulation of another recessive allele designated as SHAM RAMIFICATION 2 (SHR2) and both are located at chromosome 2AL (Amagi et al., 2014). However, the information regarding structural and functional pathway of SHR2 is still lacking (Dobrovolskaya et al., 2017). Recently, Dixon et al. (2018) elaborated the genetic factors controlling the formation of paired spikelets, a form of branched spike in hexaploid wheat. The study shows that TEOSINTE BRANCHED1 (TB1) an ortholog of maize domestication gene locus interacts with FLOWERING LOCUS T1 (FT1) to regulate the inflorescence architecture in bread wheat.

Although several studies have elaborated the inheritance and genetics of branched spike or supernumerary spike in wheat but a very few studies elaborated the molecular markers linked to these traits (Echeverry-Solarte et al., 2014). Dobrovolskaya et al. (2009) reported the mapping of a major locus controlling multi-row spike ( $m r s)$ in wheat on chromosome 2D which is linked to microsatellite locus $X w m c 453$. Similarly, a QTL flanking two SSR markers (Xgwm275 and Xgwm122) was mapped on chromosome 2A in Tibetan wheat (Li et al., 2011). In T. durum Desf. var. ramosoobscurum Jakubz. "Vetvistokoloskaya" R-107 three $\mathrm{F}_{2}$ mapping populations were used to map the branched head spike. The results depicted that the trait of branched head was located on chromosome $2 \mathrm{~A}$ flanked proximally by the molecular marker Xgwm425 (Haque et al., 2012). In T. monococcum the locus of branched head $\left(b h^{m}\right)$ was mapped on chromosome $2 \mathrm{~A}^{\mathrm{m}}$ along with co-segregating marker Xgwn122 present at the distal end of the gene (Amagi et al., 2014). The detailed mechanism of supernumerary and spike branching trait development in wheat based on above discussion is presented in Figure 2.

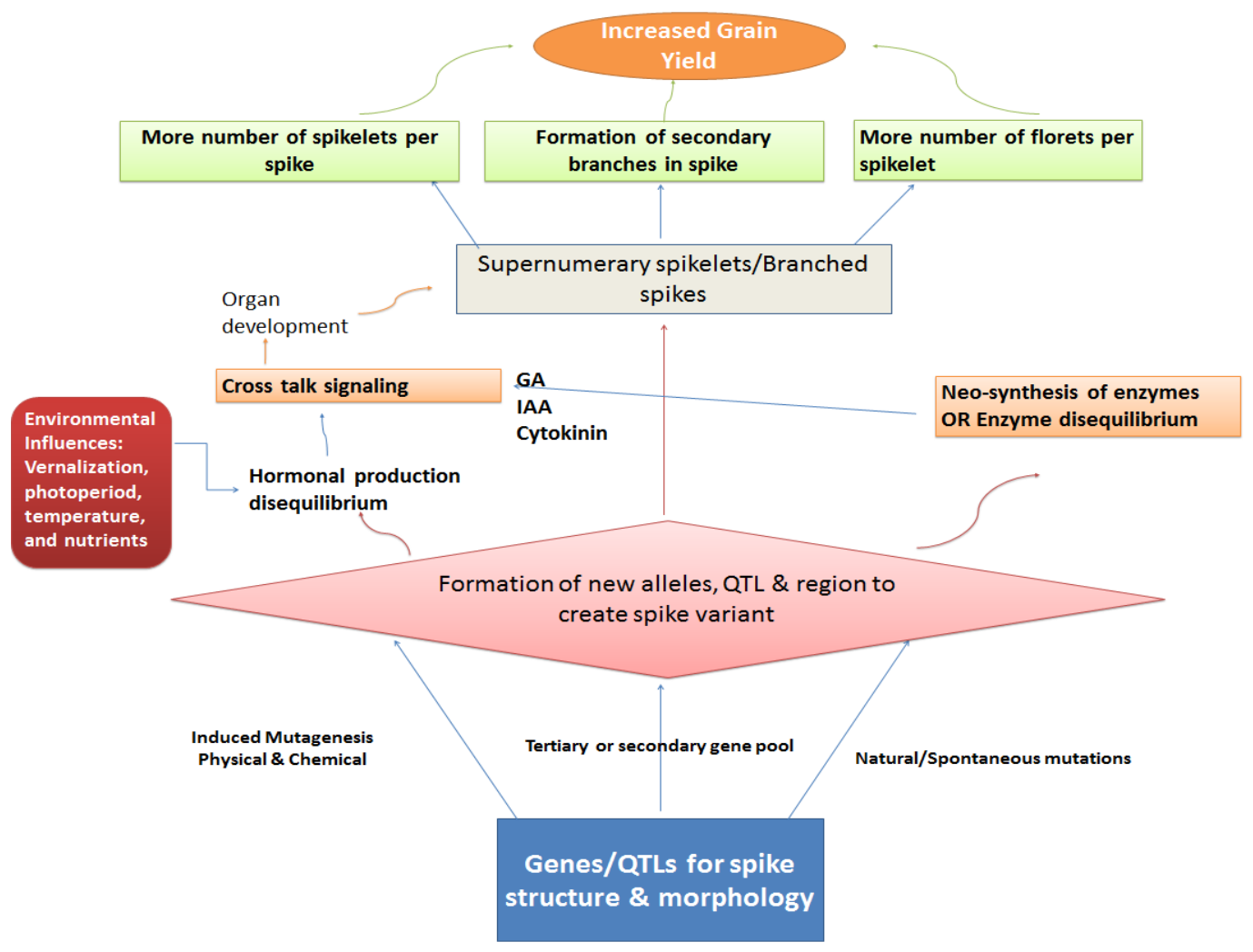

Figure 2. Mechanism of Supernumerary Spikelet and Branched Spike Development 


\section{Grain Yield and Quality of Normal vs. Supernumerary Spikelet and Branched Spike}

The impact of supernumerary spikelet on other agronomically important yield contributing traits is not clearly mentioned in literature; however, some studies have found that branched head genotypes are negatively correlated with yield contributing traits including reduced tillering, low grain weight, some sterile florets, delayed heading and maturity (Hucl and Fowler, 1992) and ultimately less grain yield (Zhang et al., 2012). However, some branched genotypes defy these generalizations (Martinek and Bednar, 1998). For example, some lines in Tibetan Triple-Spikelet wheat have good grain production with more than 120 seeds per spike and appropriate thousand grain weight (Yang et al., 2005). Miracle wheat, a highly stable phenotype with branched spikes has a higher yield potential as compared to unbranched tetraploid wheats (Poursarebani et al., 2015). Further, it has also been observed that grain yield of such genotypes can be enhanced by improving the fertility of sterile florets (Pennell and Halloran, 1984a,b).

Quality of supernumerary grains is extremely important for the end users. Traits like; starch (amylose and amylopectin), proteins and gluten protein contents are important to focus. Limited information is available about the quality of these grains. Few of the recent studies of genome wide association (GWA) revealed that gluten protein contents were positively correlated with supernumerary spikes (Echeverry-Solarte et al., 2015). Singh et al. (2018) pointed out that next generation sequencing coupled with haplotypebased approaches can be helpful to detect the real changes in multiple environments. These results are encouraging for the plant scientists; however, further studies are required to explain the quality of grains and their products.

\section{Influence of Environmental Conditions}

The degree of supernumerary spikelet and ear branching appearance in wheat is strongly associated to environmental effects. Tendency of both tetraploid and hexaploid wheats towards branched headings differs under different vernalization, photoperiod, temperature, moisture and nutrient regimes (Sharman, 1967; Pennell and Halloran, 1984a,b).

\section{Vernalization}

Ups and downs in the required vernalization of wheat affect the potential seed number per head. Similarly, the branched spike and supernumerary spikelet expression is influenced by vernalization. Pennell and Halloran (1984a) studied two tetraploid and six hexaploid wheats with branched spike tendency and found that the expression differed in lines with strong vernalization response. They also indicated high stability in the expression of supernumerary spikelet in certain genotypes especially under different environments and their potential to incorporate this character in breeding material or commercial wheat varieties to increase grain number per head.

\section{Photoperiod}

Day length is also crucial to express the potential of supernumerary spikelets into grain yield. Pennell and Halloran (1984b) reported that wheats with tendency of branched heads develop more supernumerary spikelets in short photoperiod 
environment (9-14 h) with weak vernalization. The expression of this character was high in long photoperiod environment $(24 \mathrm{~h})$ lines having strong vernalization response. Sharman (1967) also reported significant expression under short photoperiods whereas Rawson and Ruwali (1972b) found that the initiation of supernumerary spikelet takes longer photoperiod than in normal wheat. Fedorov (1955) also indicated length of the day as main conducive factor.

\section{Temperature/Time of Sowing}

The variations in spike morphology especially spike branching is strongly associated with time of sowing and mean minimum and maximum temperature at the time of heading. Sharman (1967) reported that the branching in wheat is caused by a recessive gene and appear only in normal or low temperature conditions and inhibited at longer day length or high temperature. Pennell and Halloran (1984b) also endorsed these findings. Meena et al. (2008) reported the occurrence of hetero-branching spike in bread wheat at different temperature and sowing times. The mean minimum and maximum temperatures at heading stage during early sown crop were $6.90^{\circ} \mathrm{C}$ and $22.79^{\circ} \mathrm{C}$ while the corresponding figures under late sown conditions were $8.39^{\circ} \mathrm{C}$ and $24.09^{\circ} \mathrm{C}$. They characterized the most striking morphotypes having two fully developed spikes on a single culm. Such morphotypes were expressed only in early sown $\mathrm{F}_{2}$ generation. There was no such type of segregation observed in $\mathrm{F}_{2}$ material sown late in December. It may be due to low heritability of the character and threshold controlled by one or more recessive genes at various temperatures.

\section{Nutrients}

Appearance of branched spike is not limited to environmental conditions and is hereditary (Masubuchi, 1974). This trait is strongly influenced by nutritional conditions. Vigolov's (1954) reported that branched spikes can be obtained from fertile soils. Ryzei (1950) also produced branched wheat after removing the majority of the spikelets and gave abundant nutrition to the remaining spikelets. Ryzei (1950), Muhin (1952) and Vigolov (1954) observed nutritional conditions as main influencing factors on the plant to produce branched heads. Reduced grain weight or size in branched spike might be the result of other factors like less nutrition, or compact grain in a spike (Koric, 1975).

\section{Future Prospects}

\section{Genome Wide Association Mapping}

Spike length, grain number and size have extensively been studied in the recent to identify the genomic regions associated with these traits (Singh et al. 2018; RehmanArif et al. 2020; Shokat et al. 2020). Studies investigated the underlying QTLs/genes in branched genotypes and studied the association of agronomically important traits (AIT) in these genotypes on the basis of phenotypic analysis. Some molecular marker studies also identified genetic regions controlling the spike branching trait ( $\mathrm{Li}$ et al., 2011; Echeverry-Solarte et al., 2014), but to date only one study investigated the association of these genetic regions with AIT using genome wide association mapping (GWAS). Echeverry-Solarte et al. (2015) evaluated several recombinant inbred lines from a cross between WCB414 $\times$ WCB617, a normal and branched spike phenotype, respectively. 
They identified QTLs associated with nine spike related traits and 10 AIT, and found chromosome 2DS rich for these characters. Therefore, GWAS can be used to detect QTLs for spike branching, supernumerary spikelet and AIT of bread wheat. It can also identify common genomic regions with QTL for spike related and AIT and also to explore novel alleles with possible use in breeding wheat improvement programs.

\section{Next Generation Sequencing}

In comparison to 1950s, a massive increase in our information about the biological basis of plant productivity has opened new prospects for novel breeding strategies. The large and complex genome of bread wheat represents a big challenge, but at the same time offers a large reservoir of genes that can be targeted to breed for desired traits (Nadolska-Orczyk et al., 2017). Detailed description and an analysis of the reference sequence of the hexaploid wheat genome by International Wheat Genome Sequencing Consortium (IWGSC), paved the way for the development of wheat varieties resilient to climate changes, endowed with higher yields, improved nutritional quality and sustainability (Appels et al., 2018). Now, genes involved in supernumeric wheat can be easily exploited following reference sequence. Next generation sequencing (NGS) can be used to sequence these genes and to understand the mechanism of supernumerary spikelet development at genetic level. This technique can also pave the way for expression analysis of these genes in the source material or otherwise their transformation in the elite bread wheat germplasm.

\section{Gene Pyramiding}

Pyramiding of elite alleles for dynamic development of spike branching in bread wheat can be rewarding. Even researchers have combined different spike branching genes to develop near isogenic lines in wheat (Zhang et al., 2012). However, very little research has been focused on the effects of pyramiding spike branching genes on AIT in bread wheat. This is due to lack of suitable materials and unfavorable environmental influences (Zhao et al., 2012). These results are encouraging for the plant scientists; however, further studies are required to explain the effects of combining spike branching genes on agronomically important traits in bread wheat.

\section{Speed Breeding}

Recent advances in generation advancement in plant breeding research i.e. "Speed Breeding" by Watson et al. (2018) can be potentially utilized to understand the optimum environment required for the expression of supernumerary or spike branching trait in wheat. Speed breeding protocols can be used for modeling the ideal photoperiod, temperature and nutrient conditions that favor the expression of these traits. Hence, genetic control of spike branching in relation with environmental influences can be exploited and rationalized.

\section{Conclusion}

Supernumerary spikelet and branched spikes holds enormous potential for boosting number of grains/spike and ultimately wheat yield. These are genetically controlled and can be exploited in future breeding programs. Although some negative correlations among other yield components and environments put hindrance to use these traits for 
the development of commercial high yielding wheat cultivars. However, possibilities are there to break these strong linkages through plant improvement approaches and by modeling the ideal photoperiod, temperature and nutrient conditions that favor the expression of these traits. Recent approaches of next generation sequencing can be helpful to investigate these traits more precisely. Likewise, certain physiological aspects, along with plant signaling are yet to be covered. Additionally, workload management from source to sink is also not been studied yet. Despite of all missing information, still these traits can be exploited and their maintained germplasm sources can be utilized to improve yield potential in this globally important crop.

\section{REFERENCES}

[1] Aliyeva, A. J., Aminov, N. K. (2011): Inheritance of the branching in hybrid populations among tetraploid wheat species and the new branched spike line 166-Schakheli. - Genetic Resources and Crop Evolution 58: 621-628.

[2] Amagai, Y., Martinek, P., Watanabe, N., Kuboyama, T. (2014): Microsatellite mapping of genes for branched spike and soft glumes in Triticum monococcum L. - Genetic Resources and Crop Evolution 61: 465-471.

[3] Amagai, Y., Gowayed, S., Martineck, P., Watanabe, N. (2017): The third glume phenotype is associated with rachilla branching in the spikes of tetraploid wheat. Genetic Resources and Crop Evolution 64: 835-842.

[4] Appels, R., Eversole, K., Feuillet, C., Keller, B., Rogers, J., Stein, N., Pozniak, C. J., Choulet, F., Distelfeld, A., Poland, J., Ronen, G. (2018): Shifting the limits in wheat research and breeding using a fully annotated reference genome. - Science 361: 7191.

[5] Barazesh, S., McSteen, P. (2008): Hormonal control of grass inflorescence development. - Trends in Plant Science 13: 656-662.

[6] Benjamins, R., Scheres, B. (2008): Auxin: the looping star in plant development. Annual Review of Plant Biology 59: 443-465.

[7] Beveridge, C. A. (2006): Axillary bud outgrowth: sending a message. - Current Opinions in Plant Biology 9: 35-40.

[8] Boden, S. A., Cavanagh, C., Cullis, B. R., Ramm, K., Greenwood, J., Finnegan, E. J., Trevaskis, B., Swain, S. M. (2015): Ppd-1 is a key regulator of inflorescence architecture and paired spikelet development in wheat. - Nature Plants 1: 14016.

[9] Bomblies, K., Wang, R. L., Ambrose, B. A., Schmidt, R. J., Meeley, R. B., Doebley, J. (2003): Duplicate FLORICAULA/LEAFY homologs zfll and zfl2 control inflorescence architecture and flower patterning in maize. - Development 130: 2385-2395.

[10] Bommert, P., Satoh-Nagasawa, N., Jackson, D., Hirano, H. Y. (2005): Genetics and evolution of inflorescence and flower development in grasses. - Plant Cell Physiology 46: 69-78.

[11] Bortiri, E., Hake, S. (2007): Flowering and determinacy in maize. - Journal of Experimental Botany 58: 909-916.

[12] Cheng, Y. F., Zhao, Y. D. (2007): A role for auxin in flower development. - Journal of Integrative Plant Biology 49: 99-104.

[13] Chuck, G., Muszynski, M., Kellogg, E., Hake, S., Schmidt, R. J. (2002): The control of spikelet meristem identity by the branched silkless 1 gene in maize. - Science 298: 12381241.

[14] Dahlgren, B. E. (1922): Wheat. - Field Museum of. Nat. Hist., Chicago.

[15] de Candolle, A. (1883): Origine des plantes cultivées. - Vol. 43, G. Baillière et cie.

[16] Delker, C., Raschke, A., Quint, M. (2008): Auxin dynamics: the dazzling complexity of a small molecule's message. - Planta 227: 929-941. 
[17] Dencic, S. (1988): Genetic analysis of different structures of sink capacity in wheat. - In: Miller, T. E., Koebner, R. M. D. (eds.) Proc. Int. Wheat Genet. Symp., 7th, Cambridge, UK, 13-19 July 1988. Bath Press, Bath, Avon, England. pp. 499-502.

[18] Dixon, L. E., Greenwood, J. R., Bencivenga, S., Zhang, P., Cockram, J., Mellers, G., Ramm, K., Cavanagh, C., Swain, S. M., Boden, S. A. (2018): TEOSINTE BRANCHED1 Regulates Inflorescence Architecture and Development in Bread Wheat (Triticum aestivum L.). - The Plant Cell 30(3): 563-581.

[19] Dobrovolskaya, O., Martinek, P., Voylokov, A. V., Korzun, V., Roder, M. S., Borner, A. (2009): Microsatellite mapping of genes that determine supernumerary spikelets in wheat (T. aestivum) and rye (S. cereale). - Theoretical and Applied Genetics 119: 867-874.

[20] Dobrovolskaya, O. B., Badaeva, E. D., Adonina, I. G., Popova, O. M., Krasnikov, A. A., Laikova, L. I. (2014): Investigation of morphogenesis of inflorescence and determination of the nature of inheritance of "supernumerary spikelets" trait of bread wheat (Triticum aestivum L.) mutant line. - Russian Journal of Developmental Biology 45: 361-366.

[21] Dobrovolskaya, O., Pont, C., Sibout, R., Martinek, P., Badaeva, E., Murat, F., Chosson, A., Watanabe, N., Prat, E., Gautier, N., Gautier, V., Poncet, C., Orlov. Y. L., Krasnikov, A. A., Berges, H., Salina, E., Laikova, L., Salse, J. (2015): FRIZZY PANICLE drives supernumerary spikelets in bread wheat. - Plant Physiology 167: 189-199.

[22] Dobrovolskaya, O. B., Amagai, Y., Popova, K. I., Dresvyannikova, A. E., Martinek, P., Krasnikov, A. A., Watanabe, N. (2017): Genes WHEAT FRIZZY PANICLE and SHAM RAMIFICATION 2 independently regulate differentiation of floral meristems in wheat. BMC Plant Biology 17: 252.

[23] Doebley, J. F., Gaut, B. S., Smith, B. D. (2006): The molecular genetics of crop domestication. - Cell 127: 1309-1321.

[24] Dorofeev, V. F., Korovina, O. N. (1979): Wheat. - Flora of Cultivated Plants, Vol. 1. Kolos, Leningrad. 347p.

[25] Echeverry-Solarte, M., Kumar, A., Kianian, S., Mantovani, E. E., Simsek, S., Alamri, M. S., Mergoum, M. (2014): Genome-wide genetic dissection of supernumerary spikelet and related traits in common wheat. - The Plant Genome 7(3): 1-16.

[26] Echeverry-Solarte, M., Kumar, A., Kianian, S., Mantovani, E. E., McClean, P. E., Deckard, E. L., Elias, E., Simsek, S., Alamri, M. S., Hegstad, J., Schatz, B. (2015): Genome-wide mapping of spike-related and agronomic traits in a common wheat population derived from a supernumerary spikelet parent and an elite parent. - The Plant Genome 8(2): 1-20.

[27] Fedorov, A. K. (1955): The effect of light during the autumn period upon branching and productivity of the ear. - Trudy Institute Genetiki 22: 116-120.

[28] Gepts, P. (2004): Crop domestication as a long-term selection experiment. - Plant Breeding 24: 1-44.

[29] Glemin, S., Bataillon, T. (2009): A comparative view of the evolution of grasses under domestication. - New Phytologist 183: 273-290.

[30] Godfray, H. C. J., Beddington, J. R., Crute, I. R., Haddad, L., Lawrence, D., Muir, J. F., Pretty, J., Robinson, S., Thomas, S. M., Toulmin, C. (2010): Food security: the challenge of feeding 9 billion people. - Science 327: 812-818.

[31] Gross, B. L., Olsen, K. M. (2010): Genetic perspectives on crop domestication. - Trends in Plant Science 15: 529-537.

[32] Haque, M. A., Martinek, P., Kobayashi, S., Kita, I., Ohwaku, K., Watanabe, N., Kuboyama, T. (2012): Microsatellite mapping of the genes for semi-dwarfism and branched spike in Triticum durum Desf. var. ramosoobscurum Jakubz. "Vetvistokoloskaya". - Genetic Resources and Crop Evolution 59: 831-837.

[33] Hucl, P., Fowler, B. J. (1992): Comparison of branched spike wheat with the cultivars Neepawa and HY320 for grain yield and yield components. - Canadian Journal of Plant Science 72: 671-677. 
[34] Klindworth, D. L., Williams, N. D., Joppa, L. R. (1990): Chromosomal location of genes for supernumerary spikelet in tetraploid wheat. - Genome 33: 515-520.

[35] Klindworth, D. L., Klindworth, M. M., Williams, N. D. (1997): Telosomic mapping of four genetic markers in durum wheat. - Journal of Heredity 88: 229-232.

[36] Komatsu, M., Chujo, A., Nagato, Y., Shimamoto, K., Kyozuka, J. (2003): FRIZZY PANICLE is required to prevent the formation of axillary meristems and to establish floral meristem identity in rice spikelets. - Development 130: 3841-3850.

[37] Konopatskaia, I., Vavilova, V., Blinov, A., Goncharov, N. P. (2016): Spike morphology genes in wheat species (Triticum L.). - Proceedings of the Latvian Academy of Sciences. Section B. Natural, Exact, and Applied Sciences 70: 345-355.

[38] Koric, S. (1973): Branching genes in Triticum aestivum. - Proceedings of the $4^{\text {th }}$ International Wheat Genetics Symposium, Columbia, MO, University of Missouri, MO, pp. 283-288.

[39] Koric, S. (1975): Genetic basis for high spike productivity. - Proceedings of the $2^{\text {nd }}$ Intern Winter Wheat Conference, Zagreb, Yugoslavia. U.S. Department of Agriculture, pp. 144188.

[40] Kyozuka, J., Konishi, S., Nemoto, K., Izawa, T., Shimamoto, K. (1998): Down-regulation of $R F L$, the $F L O / L F Y$ homolog of rice, accompanied with panicle branch initiation. Proceedings of the National Academy of Sciences 95: 1979-1982.

[41] Kyozuka, J. (2007): Control of shoot and root meristem function by cytokinin. - Current Opinions in Plant Biology 10: 442-446.

[42] Lawlor, D. W., Paul, M. J. (2014): Source/sink interactions underpin crop yield: the case for trehalose 6-phosphate/SnRK1 in improvement of wheat. - Frontiers in Plant Science 5: 418.

[43] Lenser, T., Theiben, G. (2013): Molecular mechanisms involved in convergent crop domestication. - Trends in Plant Science 18: 704-714.

[44] Li, W. P., Zhao, W. M. (2000): A breeding method for increasing spikelet and studies on creation of new germplasm resource in wheat. - Acta Agronomy Sinica 26: 222-230.

[45] Li, J., Wang, Q., Wei, H., Hu, X., Yang, W. (2012): SSR mapping for locus conferring on the triple-spikelet trait of the Tibetan triple-spikelet wheat (Triticum aestivum L. concv. tripletum). - Triticeae Genomics and Genetics 2(1): 1-6.

[46] Martinek, P., Bednár, J. (1998): Gene resources with non-standard spike morphology in wheat. - In: Slinkard, A. (ed.) Proc. of the $9^{\text {th }}$ Int. Wheat Genetic Symp., 2-7 Aug., Saskatoon, SK, Canada, pp. 286-288.

[47] Masubuchi, N. (1974): Genetical studies of branched spikes in soft wheat. - Journal of Faculty of Science, Hokkaido Univ. Series V. (Botany) 10: 85-112.

[48] McSteen, P., Laudencia-Chingcuanco, D., Colasanti, J. (2000): A floret by any other name: control of meristem identity in maize. - Trends in Plant Science 5: 61-66.

[49] McSteen, P., Leyser, O. (2005): Shoot branching. - Annual Review Plant Biology 56: 353-374.

[50] McSteen, P. (2009): Hormonal Regulation of Branching in Grasses. - Plant Physiology 149: 46-55.

[51] Meena, B. K., Rawat, R. S., Jag, S., Verma, J. S., Shukla, A. K. (2008): Occurrence of hetero-branching of spike in bread wheat (T. aestivum L.). - Proceedings of $11^{\text {th }}$ International Wheat Genetic Symposium 1: 241-243.

[52] Miralles, D. J., Slafer, G. A. (2007): Sink limitations to yield in wheat: how could it be reduced? - Journal of Agricultural Science Cambridge 145: 139.

[53] Muhin, N. D. (1952): Changing normal soft spring wheats into branching forms. Agrobiologiya 4: 114-119.

[54] Nadolska-Orczyk, A., Rajchel, I. K., Orczyk, W., Gasparis, S. (2017): Major genes determining yield-related traits in wheat and barley. - Theoretical and Applied Genetics 130: $1081-1098$. 
[55] Ongaro, V., Leyser, O. (2008): Hormonal control of shoot branching. - Journal of Experimental Botany 59: 67-74.

[56] Pearce, S., Vanzetti, L. S., Dubcovsky, J. (2013): Exogenous gibberellins induce wheat spike development under short days only in the presence of VERNALIZATION1. - Plant Physiology 163: 1433-1445.

[57] Peng, Z. S., Yen, C., Yang, J. L. (1998): Chromosomal location of genes for supernumerary spikelet in bread wheat. - Euphytica 103: 109-114.

[58] Pennell, A. L., Halloran, G. M. (1983): Inheritance of supernumerary spikelets in wheat. - Euphytica 32: 767-776.

[59] Pennell, A. L., Halloran, G. M. (1984a): Influence of vernalization and photoperiod on supernumerary spikelet expression in wheat. - Annals of Botany 53: 821-831.

[60] Pennell, A. L., Halloran, G. M. (1984b): Influence of time of sowing, photoperiod and temperature on supernumerary spikelet expression in wheat (Triticum). - Canadian Journal of Botany 62: 1687-1692.

[61] Percival, J. (1921): The wheat plant. - Duckworth and Co., London

[62] Poursarebani, N., Seidensticker, T., Koppolu, R., Trautewig, C., Gawroñski, P., Bini, F., Govind, G., Rutten, T., Sakuma, S., Tagiri, A., Wolde, G. M., Youssef, H. M., Battal, A., Ciannamea, S., Fusca, T., Nussbaumer, T., Pozzi, C., Borner, A., Lundqvist, U., Komatsuda, T., Salvi, S., Tuberosa, R., Uauy, C., Sreenivasulu, N., Rossini, L., Schnurbusch, T. (2015): The genetic basis of composite spike form in barley and "miracle-wheat". - Genetics 201: 155-165.

[63] Rawson, H. M., Ruwali, K. N. (1972a): Branched ears in wheat and yield determination. - Ibid 23: 541-549.

[64] Rawson, H. M., Ruwali, K. N. (1972b): Ear branching as a means of increasing grain uniformity in wheat. - Australian Journal of Agricultural Research 23: 551-559.

[65] Rehman-Arif, M. A., Attaria, F., Shokat, S., Akram, S., Waheed, M. Q., Arif, A., Börner, A. (2020). Mapping of QTLs associated with yield and yield related traits in durum wheat (Triticum durum Desf.) under irrigated and drought conditions. - International Journal of Molecular Sciences 21(7):2372.

[66] Ryzei, I. P. (1950): Development of soft winter wheats with ears producing many grains. - Selektsiya i Semenovodstvo 12: 22-27.

[67] Shani, E., Yanai, O., Ori, N. (2006): The role of hormones in shoot apical meristem function. - Current Opinions in Plant Biology 9: 484-489.

[68] Sharman, B. C. (1944): Branched heads in wheat and wheat hybrids. - Nature 153: $497-$ 498.

[69] Sharman, B. C. (1967): Interpretation of the morphology of various naturally occurring abnormalities of the inflorescence of wheat (Triticum sp.). - Canadian Journal of Botany 45: 2073-80.

[70] Shokat, S., Sehgal, D., Vikram, P., Liu, F., Singh, S. (2020). Molecular markers associated with agro-physiological traits under terminal drought conditions in bread wheat. - International Journal of Molecular Sciences 21(9): 3156.

[71] Simon, R., Igeno, M. I., Coupland, G. (1996): Activation of floral meristem identity gene in Arabidopsis. - Nature 7: 59-62.

[72] Singh, N., Wu, S., Raupp, J., Sehgal, S., Arora, S., Tiwari, V., Vikram, P., Singh, S., Chhuneja, P., Gill, B., Poland, J. (2018): Efficient curation of genebanks using next generation sequencing reveals substantial duplication of germplasm accessions. Scientific Reports 9: 650.

[73] Singh, S., Vikram, P., Sehgal, D., Burgueño, J., Sharma, A., Singh, S. K., Sansaloni, C. P., Joynson, R., Brabbs, T., Ortiz, C., Solis-Moya, E. (2018): Harnessing genetic potential of wheat germplasm banks through impact-oriented-prebreeding for future food and nutritional security. - Scientific Reports, 8: 1-11.

[74] Swaminathan, M. S., Chopra, V. L., Ststry, G. R. K. (1966): Expression and stability of induced mutation for branching in bread wheat. - Current Science 35: 91-92. 
[75] Tetsuka, K. (2001): Physiological aspects of the supernumerary spikelets formation in wheat. - Proceedings of Asian Agriculture Congress, 166.

[76] Thompson, B. E., Hake, S. (2009): Translational biology: from Arabidopsis flowers to grass inflorescence architecture. - Plant Physiology 149: 38-45.

[77] Tschermak, E. (1914): Über die Vererbungsweise von Art- und Gattungsbastarden innerhalb der Getreidegruppe. (On the inheritance of species- and genus-hybrids among cereals). - Mitt. landw. Lehrkanzeln k. k. Hochschule für Bodenkultur Wien II.

[78] Vigolov, L. I. (1954): Modes of developing branched ears in soft spring wheats. - Bjull. Mosk. Obshch. Ispyt. Prirod. 5: 53-58.

[79] Wang, Y., Miao, F., Yan, L. (2016): Branching shoots and spikes from lateral meristems in bread wheat. - PLoS ONE 11(3): e0151656.

[80] Wang, Y., Sun, F. L., Gao, Q. R., Zhang, Y. X., Wang, N., Zhang, W. D. (2017): Auxin regulations of branched spike development and expression of TFL, a LEAFY-like gene in branched spike wheat (Triticum Aestivum). - Journal of Agricultural Science 9(2): 27.

[81] Watson, A., Ghosh, S., Williams, M. J., Cuddy, W. S., Simmonds, J., Rey, M. D., Hatta, M. A. M., Hinchliffe, A., Steed, A., Reynolds, D., Adamski, N. M. (2018): Speed breeding is a powerful tool to accelerate crop research and breeding. - Nature Plants 4: 23.

[82] Yamaguchi, N., Wu, M. F., Winter, C. M., Wagner, D. (2014): LEAFY and polar auxin transport coordinately regulate arabidopsis flower development. - Plants (Basel) 30: 25165 .

[83] Yang, W. Y., Lu, B. R., Hu, X. R., Yu, Y., Zhang, Y. (2005): Inheritance of the triplespikelet character in a Tibetan landrace of common wheat. - Genetic Resources and Crop Evolution 52: 847-851.

[84] Yen, C., Zheng, Y. L., Yang, J. L. (1993): An ideotype for high yield breeding, in theory and practice. - Proc. $8^{\text {th }}$ Intern. Wheat Genet. Symp., Beijing, China, pp. 1113-1117.

[85] Yuan, W., Sun, Y., Zhang, M., Pei, Z., Sun, S., Li, P., Feng, R. (1994): Genetics study on common wheat with branched spike transferred from Triticum turgidum Compositum. Acta Agriculturae Boreali-Sinica 10: 45-50.

[86] Zhang, W., Li, A., Tian, J., Zhao, L. (2012): Development of near isogenic lines of wheat carrying different spike branching genes and their agronomic and spike characters. Journal of Agricultural Science 4: 215-221.

[87] Zhang, R. Q., Fu, H. O., Juan, C. H., Chen, S. L., Xing, L. P., Feng, Y. G., Cao, A. Z. (2017): Agronomic characterization and genetic analysis of the supernumerary spikelet in tetraploid wheat (Triticum turgidum L.). - Journal of Integrative Agriculture 16: 1304-11.

[88] Zhao, Y. (2008): The role of local biosynthesis of auxin and cytokinin in plant development. - Current Opinions in Plant Biology 11: 16-22.

[89] Zhao, L., Zhang, W., Gao, Q., Li, A., Tian, J. (2012): Characters of rachis and grain within different spike parts in spike hetero branching wheat (Triticum aestivum L.). Journal of Agricultural Sciences 4: 106-115. 